\title{
Alternaria alternata as a Seed-Transmitted Pathogen of Sida hermaphrodita (Malvaceae) and Its Suppression by Aureobasidium pullulans
}

\author{
Urszula Wachowska $^{1, * \mathbb{C}}$, Edyta Kwiatkowska ${ }^{1}$ and Wioletta Pluskota ${ }^{2}$ \\ 1 Department of Entomology, Phytopathology and Molecular Diagnostic, University of Warmia and Mazury in \\ Olsztyn, Prawocheńskiego 17, 10721 Olsztyn, Poland; edyta.jazwinska@uwm.edu.pl \\ 2 Department of Plant Physiology, Genetics and Biotechnology, University of Warmia and Mazury in Olsztyn, \\ Oczapowskiego 1A, 10-719 Olsztyn, Poland; wioletta.pluskota@uwm.edu.pl \\ * Correspondence: urszula.wachowska@uwm.edu.pl
}

check for updates

Citation: Wachowska, U.; Kwiatkowska, E.; Pluskota, W. Alternaria alternata as a

Seed-Transmitted Pathogen of Sida hermaphrodita (Malvaceae) and Its Suppression by Aureobasidium pullulans. Agriculture 2021, 11, 1264. https://doi.org/10.3390/ agriculture11121264

Academic Editor: Hilary Mayton

Received: 10 November 2021

Accepted: 7 December 2021

Published: 14 December 2021

Publisher's Note: MDPI stays neutral with regard to jurisdictional claims in published maps and institutional affiliations.

Copyright: (c) 2021 by the authors. Licensee MDPI, Basel, Switzerland. This article is an open access article distributed under the terms and conditions of the Creative Commons Attribution (CC BY) license (https:// creativecommons.org/licenses/by/ $4.0 /$ )
Abstract: Background: Sida hermaphrodita (Virginia fanpetals) was introduced to Poland nearly 70 years ago as a potential fodder plant, and it is gaining importance as an energy crop. Alternaria alternata transmitted by seeds may exert a negative effect on the health of Virginia fanpetals plants. Methods: The virulence of the A. alternata pathogen, isolated from Virginia fanpetals seeds, was tested on detached leaves of Virginia fanpetals plants. The isolates were identified as A. alternata based on partial sequence analysis of Alta1, TEF1 $a$ and $g d p$ genes and the ITS 1-5.8SrDNA-ITS 2 region. Pathogen transmission from seeds to seedlings and the influence of seed dressing with a suspension of Aureobasidium pullulans on seedling health were analyzed in a greenhouse experiment. Results: Three of the nine analyzed A. alternata isolates were highly pathogenic for $S$. hermaphrodita. The initial symptoms of leaf infection were small, round dark brown or black spots which grew into larger dark brown spots surrounded by a chlorotic halo. Alternaria alternata was re-isolated from inoculated plants and was identified as the causal agent of Alternaria leaf spot disease. In the greenhouse experiment, S. hermaphrodita seeds dressed with a suspension of A.pullulans and inoculated with $A$. alternata produced a higher number of seedlings with a higher health status than non-dressed seeds. Conclusions: The study demonstrated that A. alternata is transmitted from infected S. hermaphrodita seeds to developing plants and biological control limits this phenomenon.

Keywords: black spot pathogen; pathogenicity; seed-transmitted disease; seedling emergence; Virginia fanpetals; biological control

\section{Introduction}

Sida hermaphrodita (L.) Rusby (Virginia fanpetals) is a perennial plant and a member of the family Malvaceae. It was introduced to Europe in the 1930s via southern Ukraine which conducted extensive research into the use of $S$. hermaphrodita as a fiber, fodder and nectar crop [1]. Sida hermaphrodita was introduced to Poland in the 1950s as a potential fodder plant. In addition to poplars, Salix viminalis, Miscanthus $\times$ giganteus and other rapidly growing plants, Virginia fanpetals is currently regarded as an important source of biomass for biogas and bioenergy generation in Central Europe [2]. Virginia fanpetals plantations have a long lifespan, and they supply fresh biomass for biogas production as well as dry biomass for combustion $[3,4]$. This rapidly growing plant has a wide range of applications. The phytoremediation potential of Virginia fanpetals in soils contaminated with zinc, lead, copper, nickel and pesticides has been extensively researched [5,6]. It has also been shown that extracts from Virginia fanpetals seeds have potential medicinal properties [7]. The total area under $S$. hermaphrodita continues to increase, which contributes to the spread of pathogens across regions and the emergence of new and more virulent pathogenic strains and physiological races [8]. White mold caused by Sclerotinia sclerotiorum (Lib.) de Bary 
is the most dangerous disease of Virginia fanpetals $[9,10]$. This plant is also targeted by Colletotrichum sp., Phoma sp. and Botrytis sp. which cause leaf spot diseases [11,12]. These pathogens also cause root rot of seedlings, leading to their wilting, which is an important consideration in $S$. hermaphrodita due to its low germination capacity [9-12].

Biological protection of energy crops against pathogens is an important issue in the context of the European Green Deal [13], a strategy that was introduced to decrease pesticide use in agriculture. Biological protection of energy crops remains insufficiently investigated in the literature, and most studies focus on the protection of plants in early stages of development [14] or the selection of potential microbial isolates with antagonistic activity against plant pathogens $[15,16]$. For example, Trichoderma atroviride isolates improved the growth of Miscanthus $\times$ giganteus seedlings in a greenhouse and reduced the prevalence of infections caused by Rhizoctonia solani [Kandula et al. 2020]. Yeasts selected by Remlain-Starosta et al. [15] inhibited the in vitro development of S. sclerotiorum pathogens isolated from the stems of $S$. hermaphrodita plants. Selected Bacillus subtilis isolates from soil limited the development of the Colletotrichum gleosporioides pathogen and, according to Huang et al. [16], these isolates are promising biocontrol agents against poplar anthracnose. Despite the increase in farmland area dedicated to energy crops, commercial biological preparations for protecting energy crops have not been introduced to date.

The fungus Alternaria alternata (Fr.) Keissler is a widespread facultative pathogen of many economically important plants, including cereals, rape, apple, broccoli, cauliflower, potato, tomato, citrus fruit, pear, strawberry and tobacco [17]. In recent years, A. alternata was reported as the causal agent of leaf blight of sunflower and coriander in South Africa [8,17], brown leaf spot of cast iron plants (Aspidistra elatior) in Italy [18], postharvest fruit rot of peach in Pakistan [19], leaf spot of Hibiscus syriacus in Italy [20], leaf spot disease of Abelmoschus esculentus [21], and Alternaria brown spot of mandarins in Spain [22]. In energy crop plantations, the A. alternata pathogen was identified on switchgrass [23], Salix spp. [24] and Miscanthus spp. [25]. An epidemiological study conducted in Spain revealed the presence of pathogenic $A$. alternata isolates in the canopies of mandarin trees, on fallen leaves and in the air [Bassimba et al. 2014]. Mandarin trees were infected mainly in spring and fall when precipitation reached $\geq 2.5 \mathrm{~mm}$ and average temperature was $\geq 12.5^{\circ} \mathrm{C}$ [22]. The symptoms of A. alternata infection on $S$. hermaphrodita have not been described to date, and the progression of the disease in this plant species remains unknown. The role played by infected seeds in the spread of the disease, and the pathogenicity of A. alternata for Virginia fanpetals seedlings have never been investigated.

Alternaria alternata is ubiquitous in the environment, and it is identified not only in field crops, but also in plants grown indoors [26]. The spores of this fungal species have been widely researched as the sources of biological contamination and potent allergens [27]. Field crops are most exposed to A. alternata allergens, and the Alt a1 protein is the main cause of fungal allergies in humans [27]. Salo et al. [26] demonstrated that exposure to A. alternata in homes is positively associated with asthma. Alternaria alternata produces more than 70 phytotoxins, including virulence factors that elicit both specific and nonspecific immune responses in the host organism. Several toxins have been recognized by the European Food Safety Authority (EFSA) as potential risk factors for human health, including alternariol $(\mathrm{AOH})$, alternariol monomethyl ether (AME), tenuazonic acid (TeA), altenuene (ALT), and tentoxin (TEN) $[17,28]$. Our preliminary research also demonstrated that $A$. alternata infects $S$. hermaphrodita plants in plantations and produces round dark brown or black spots on leaves that increase in size over time and become surrounded by a chlorotic halo. The pathogen also colonized seeds and decreased seed germination rates.

The results of our preliminary research on $S$. hermaphrodita infections caused by $A$. alternata have prompted us to conduct further analyses aiming to: identify $A$. alternata as an infection agent of leaf and seed capsules; determine the share of $A$. alternata in filamentous fungi colonizing seeds; determine the potential transmission of $A$. alternata from seeds to seedlings, and verify the effectiveness of seed dressing with antagonistic Aureobasidium pullulans in reducing A. alternata infections. 


\section{Materials and Methods}

\subsection{Evaluation of Plant Health}

Plant health was monitored in a 5-year plantation of S. hermaphrodita (established in 2010) in Bałdy in north-eastern Poland ( $\left.53^{\circ} 36^{\prime} 01^{\prime \prime} \mathrm{N}, 20^{\circ} 36^{\prime} 14^{\prime \prime} \mathrm{E}\right)$ in 2015 . The health of Virginia fanpetals leaves and seed capsules was evaluated. Level of leaves and seed capsules infection was determined as frequency of occurrence and percentage of infected area. The leaves displaying symptoms of infection were placed in a moist chamber for $48 \mathrm{~h}$. Alternaria alternata spores on leaf spots were observed under a microscope (Nikon E200, Japan).

\subsection{Mycological Analysis of Experimental Seeds and Estimation of The Share of A. alternata}

The seeds harvested from the $S$. hermaphrodita plantation in Bałdy in 2015 were stored in paper bags at a temperature of $8{ }^{\circ} \mathrm{C}$ for 2,12 and 24 months. The share of $A$. alternata in the main groups of filamentous fungi colonizing seeds was determined by plating. One hundred seeds were randomly selected from each batch of stored seeds. The selected seeds were surface disinfected with $1 \%$ sodium hypochlorite solution for $5 \mathrm{~min}$, rinsed in sterile distilled water and dried on sterile filter paper (Chemland, Poland). The seeds were plated on Petri dishes (Abchem, Poland) filled with potato dextrose agar (PDA, Merck, Poland) with the addition of $25 \mu \mathrm{g}$ of streptomycin sulfate (Serva, Germany) and kanamycin monosulfate (A\&A Biotechnology, Poland). The plates were incubated at a temperature of $24^{\circ} \mathrm{C}$ for 7 days in an incubator (Pol-Eco, Poland). The experiment had a completely randomized design with 10 replications (10 seeds per plate per replicate). The colonies of filamentous fungi growing from seeds were counted. All colonies were identified to the species level under a light microscope (Nikon E 200, Japan) based on their sporulation characteristics [29-31].

\subsection{Morphological Analysis of Alternaria alternata}

Single-spore strains were isolated from selected cultures of the genus Alternaria obtained from seeds. The 27 cultures identified as Alternaria spp. were plated on PDA and incubated at a temperature of $24{ }^{\circ} \mathrm{C}$ for 7 days in dark in an incubator (Pol-Eco, Poland). Colonies of $A$. alternata were identified to the species level under a light microscope (Nikon E 200, Japan) based on their sporulation characteristics [30]. The prepared specimens were stored in an low temperature freezer at $-20^{\circ} \mathrm{C}$ (Pol-Eco, Poland).

\subsection{Molecular Identification of Selected A. alternata Isolates}

The nine isolates selected for molecular analyses were cultured in $25 \mathrm{~cm}^{3}$ flasks containing $10 \mathrm{~cm}^{3}$ of a liquid medium (beef extract $-1 \mathrm{~g}$, soy peptone $-5 \mathrm{~g}, \mathrm{NaCl}-5 \mathrm{~g}$, glucose $-1 \mathrm{~g}$, yeast extract $-7 \mathrm{~g} \mathrm{dm}^{-3}$ water). The flasks were incubated at $24{ }^{\circ} \mathrm{C}$ in dark (Pol-Eco, Poland) and shaken on a table shaker (Dlab Sk0330-Pro) for 4 days. Fungal filaments were strained on paper filters (Chemland, Poland) with a vacuum pump (Rocker 430, Poland) under sterile conditions, and they were transferred to Eppendorf tubes (Flmedical, Italy). The species identity of nine A. alternata isolates was confirmed by PCR. DNA was isolated with the Bead-Beat Micro AX Gravity Kit (A\&A Biotechnology, Poland) according to the manufacturer's protocol. Fungal cell walls were disrupted with the Star Beater for Molecular Biology (Bio-Strategy Ltd., Australia). A fragment of the ITS 1-5.8SrDNA-ITS 2 region was amplified with the use of universal primers, ITS5 and ITS4 [32], in the FailSafe PCR system (Epicentre, Poland). The reaction was carried out in the Mastercycler Ep Gradient (Eppendorf) thermal cycler with the following profile: denaturation at $94{ }^{\circ} \mathrm{C}$ for $2 \mathrm{~min}$, followed by 341 -min cycles at $95^{\circ} \mathrm{C}, 1 \mathrm{~min}$ at $58^{\circ} \mathrm{C}, 3 \mathrm{~min}$ at $72{ }^{\circ} \mathrm{C}$, and final elongation for $10 \mathrm{~min}$ at $72{ }^{\circ} \mathrm{C}$. Samples of $10 \mu \mathrm{L}$ were analyzed in $1.2 \%$ agarose gel. In addition, partial sequences of the translation elongation factor 1 alpha (TEF1a) gene, the allergen Alt a 1 (Alta1) gene and the glyceraldehyde-3-phosphate dehydrogenase ( $g p d)$ gene were analyzed according to the methods proposed by Duba et al. [33] for the Alta1 gene, and by Ramires et al. [34] for TEF1 $a$ and $g d p$ genes. The products were sequenced at the Institute of Biochemistry and Biophysics of the Polish Academy of Sciences [35] 
and Genomed [36]. Sequencing reactions were conducted with the use of the Applied Biosystems BigDye ${ }^{\circledR}$ Terminator v 3.1 kit (Life Technologies, Poland). Sequencing reaction products were separated in the 3730xl DNA Analyzer with a capillary array (Thermo Fisher Scientific, Poland). Sequence similarity was analyzed in the NCBI database [37].

\subsection{Isolate Accession Numbers}

Nine isolates were deposited in GenBank [37] under the following accession numbers: KX272942, KX272945, KU574270-KU574276 for the ITS 1-5.8SrDNA-ITS 2 region, OL348181-OL348183, OL409170 for Alt1 gene, OL409175-OL409177, OL348186, OL348187 for TEF1 a gene and OL409171-OL409174, OL348184, OL348185 for $g d p$ gene. Isolate sequences were compared with the sequences described by Woudenberg et al. [30] and other sequences of $A$. alternata isolates acquired from infected crops [18-20,34,38].

\subsection{Standard Seed Germination Test}

Seed germination tests according ISTA methods (International Seed Testing Association) were conducted on paper filters [39]. Fifty seeds (stored for 2 months for the seed transmission test) were placed between four layers of moistened filter paper (Chemland, Poland). Filter paper was rolled, placed in glass containers and incubated at $24^{\circ} \mathrm{C}$. The experiment was conducted in four replicates. Seeds that developed into healthy seedlings, non-germinated seeds, deformed seeds (unable to develop into healthy plants) and infected (dead) seeds were counted after 21 days of incubation.

\subsection{Pathogenicity of Alternaria alternata in The Detached Leaf Bioassay}

Nine A. alternata isolates for the detached leaf bioassay were cultured on PDA in Petri plates at $24{ }^{\circ} \mathrm{C}$ for 5 days. Fungal sporulation was stimulated with UV light (TL-D 360W/08 BLB, 360-380 nm, Philips, Poland) for $48 \mathrm{~h}$. The spores were washed off with sterile water with the use of an inoculation loop, and the resulting suspensions were passed through sterile gauze and brought to a concentration of $10^{5}$ spore cells in $1 \mathrm{~cm}^{3}$ of water in the Thoma 50 counting chamber (Marienfeld, Germany). The spore suspension with the addition of Tween 20 (0.05\%, Merck, Germany) was sprayed onto Virginia fanpetals leaves with a glass atomizer (ABchem, Poland). Leaves were obtained from four-week-old Virginia fanpetals seedlings grown in a phytotron (Hakmann s.c., Poland). Six pathogen-free leaves were tested for each isolate (total of 54 leaves), and infected leaves were incubated in a moist chamber (Petri plates with damp blotting paper) for 4 days $\left(12 / 12 \mathrm{~h}\right.$ day /night; $21 / 19{ }^{\circ} \mathrm{C}$; $80 \%$ humidity). Alternaria alternata was re-isolated from leaves showing symptoms of infection. Five segments with an area of $4 \mathrm{~mm}^{2}$ each were excised from the edges of leaves with and without disease symptoms. The segments were plated on PDA and incubated (Pol-Eco, Poland) at $24^{\circ} \mathrm{C}$ in dark for 7 days. Colonies of A. alternata were identified under a light microscope (Nikon E 200, Japan) based on their sporulation characteristics [30]. Repeated isolation of A. alternata from inoculated leaves confirmed Koch's postulates. Spore specimens were prepared with the sell tape technique and stained with lactophenol blue solution (Fluka, Poland). Images of leaf segments with symptoms of infection were acquired with the CCD scanner (Epson Perfection V370 Photo, Epson, Shinjuku, Tokyo, Japan) and saved as 24-bit color BMP files with 200 dpi resolution. Infected leaf area was measured in an image processing program ImageJ 1.49 [40].

\subsection{Seed Transmission Test and Evaluation of Seedling Health in a Greenhouse Experiment}

Twenty Virginia fanpetals seeds (stored for two months) that were or were not inoculated with the most pathogenic A. alternata isolate W 26 (as determined in the detached leaf bioassay) were planted in pots at a depth of $0.5 \mathrm{~cm}$. The seeds were inoculated by immersion in a suspension of $A$. alternata $\mathrm{W} 26$ spores for $5 \mathrm{~min}$. The suspension preparation method was identical to that described in the detached leaf bioassay. The seeds were inoculated immediately before sowing. Seedlings were grown 21 days in a greenhouse at a temperature of $23{ }^{\circ} \mathrm{C} / 19^{\circ} \mathrm{C}$ (day/night), 16/8 photoperiod (day/night), and $80 \%$ humidity. 
They were watered every two days throughout the experiment. NPK fertilizer (Azofoska, Poland, $\mathrm{N} / \mathrm{P}_{2} \mathrm{O}_{5} / \mathrm{K}_{2} \mathrm{O} 13.6 / 6.4 / 19.1 \%$ ) was applied directly to the pots three times at a rate of $2 \mathrm{~g}$. The pots had a diameter of $15 \mathrm{~cm}$ and were filled with a 1:2 soil and sand mixture. The experiment had a completely randomized design with four replications for each combination. The experiment was performed twice.

Plant health was evaluated in eight-week-old seedlings. Similarly to the detached leaf bioassay, A. alternata was re-isolated from leaves showing symptoms of infection to confirm compliance with Koch's postulates. Colonies of A. alternata were identified under a light microscope (Nikon E 200, Japan). Infection severity was evaluated based on the mean percentage of leaf surface area showing symptoms of the disease [41]. The severity of infection was estimated on all emergent seedlings on a rating scale modified for the needs of the experiment (Table 1). The results were expressed as the mean percentage leaf area showing signs of infection. The severity of A. alternata infection was also assessed based on the pathogen's ability to inhibit plant growth. Healthy leaves were counted, plant height and root length were measured. Above-ground fresh biomass weight was determined in potted plants and expressed per seedling. The germination capacity of inoculated seeds was evaluated in three-week-old seedlings, and it was expressed as the percent ratio of emerged plants to sown seeds.

Table 1. Alternaria leaf spot disease rating scale.

\begin{tabular}{cc}
\hline $\begin{array}{c}\text { Estimated Percentage Leaf } \\
\text { Area with Disease Systems }\end{array}$ & Description of Disease Severity \\
\hline 0 & No infection \\
1 & $1-5$ leaf lesions (diameter $<3 \mathrm{~mm}$ ) on leaf surface \\
5 & $5-10$ leaf lesions (diameter $3-5 \mathrm{~mm}$ ) on leaf surface \\
10 & $>10$ leaf lesions (diameter $>5 \mathrm{~mm}$ ) on leaf surface \\
\hline
\end{tabular}

\subsection{Biological Protection of Virginia Petals Seeds In Vitro and in a Greenhouse}

Virginia fanpetals seeds were dressed with the A. pullulans Ap 1 (accession number in GenBank [37]: MZ824415.1), Ap 3 (accession number in GenBank: MZ824416.1) and Ap 4 (accession number in GenBank: MZ824417.1) isolate. The isolates were obtained from wheat grain, and they were acquired and cultured according to the previously described methods [42]. Four-day old cells of A. pullulans were rinsed from the PDA medium (Merck) with sterile water using an inoculation loop. The rinsed cultures produced cell suspensions with the density of $A$. pullulans $10^{6}$ cells per $\mathrm{cm}^{3}$ of water. The seeds were treatment by immersion in a suspension of A. pullulans Ap 1, Ap 3 and Ap 4 cells for 5 min. Seeds noninoculated were the control. For the in vitro test, ten dressed seeds were placed on the PDA medium (Merck) in each Petri dish and incubated for 7 days at $24^{\circ} \mathrm{C}$. The experiment was carried out in five replications, and 50 seeds from every treatment were analyzed. Colonies of $A$. alternata were identified to the genus or species level under a light microscope (Nikon E 200) based on their sporulation characteristics [29-31].

In the greenhouse experiment, seeds were dressed with A. pullulans cell suspensions before sowing. Three A. pullulans isolates were applied separately: Ap 1, Ap 3 and Ap 4 . The seeds were immersed in fungal suspensions with a density of $10^{6}$ cells per $\mathrm{cm}^{3}$ of sterile water for $5 \mathrm{~min}$. Half of the seeds were additionally inoculated with A. alternata $\mathrm{W}$ 26 according to the method described in 2.8. Virginia fanpetals seeds were sown in pots with a diameter of $16 \mathrm{~cm}$, filled with horticultural soil and sand in a 2:1 ratio. Twenty seeds were planted in each pot. Fine Virginia fanpetals seeds $(1.99 \times 2.29 \mathrm{~mm})$ were covered (sprinkled) with a $3 \mathrm{~mm}$ layer of soil. Seedlings were grown in a greenhouse at a temperature of $23^{\circ} \mathrm{C} / 19^{\circ} \mathrm{C}$ (day/night), $16 / 8$ photoperiod (day/night), and $80 \%$ humidity. Emerged seedlings were watered with Hoagland's solution containing macronutrients and micronutrients [43]. The health status of all infected leaves was evaluated in 6-week-old seedlings. The percentage of leaf area with symptoms of infection was determined as 
follows: single spot- $1 \%$, successive spots $-2-10 \%$. The experiment had a completely randomized design with four replications.

\subsection{Data Analysis}

An analysis of variance was performed in the Statistica 13 application [44]. Post-hoc comparisons between the mean abundance of filamentous fungi colonizing seeds, and the significance of differences between the average severity of disease symptoms caused by $A$. alternata and differences in plant height, root length, number of leaves and seed germination capacity were determined in Fisher's LSD test for multiple comparisons at $p \leq 0.05$.

\section{Results}

\subsection{Disease Symptoms on Leaves and Seed Capsules}

Black spots with a diameter of $0.2 \mathrm{~mm}$, were observed on the leaves and seed capsules of Virginia fanpetals plants (Figure 1). Over time, the spots grew to $1-2 \mathrm{~cm}$ in diameter; they were brown, with a darker edge, and were surrounded by a chlorotic halo. After several days, the holes appeared inside necrotized leaf tissue. Symptoms of infection were observed in all evaluated plants, and pathogenic changes covered $1 \%$ to $10 \%$ of leaf area on average. Approximately $20 \%$ of seed capsules were also infected by A. alternata. The presence of $A$. alternata spores was determined on the surface of spots (Figure 2). Grayish filaments and spores of the analyzed pathogen were also noted on seed capsules.

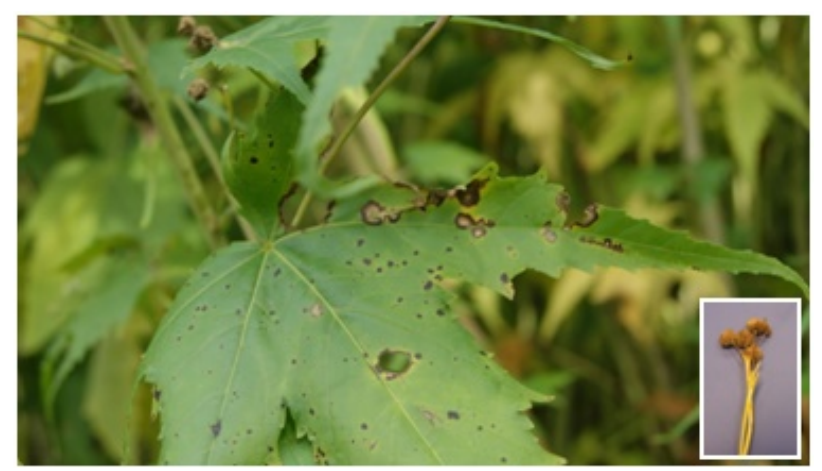

Figure 1. Symptoms of infection on the leaves and in the seed capsules (bottom right corner) of Virginia fanpetals plants.

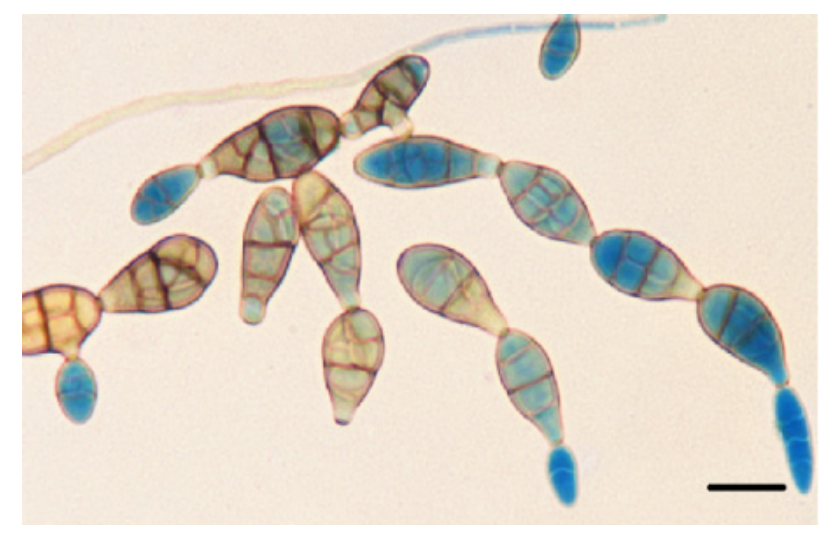

Figure 2. Spores of Alternaria alternata isolate P 11. Spore specimens were prepared with the sell tape technique and stained with lactophenol blue solution (Fluka) (scale bar $=10 \mu \mathrm{m})$.

\subsection{Evaluation of Seed Health}

Alternaria alternata was most frequently isolated from Virginia fanpetals seeds, and $18.24 \%$ to $45.09 \%$ of the seeds were colonized by this fungal species (Table 2). Significantly 
fewer A. alternata colonies were identified on the seeds that were stored for 24 months than on seeds stored for a shorter period of time. Fungi of the genus Fusarium were detected sporadically $(0.35-1.58 \%)$ or were not identified on seeds. The incidence of Penicillium and Cladosporium species was low (0-8.07\%). Colonies of the genus Cladosporium were significantly more often identified on the seeds that were stored for 2 months than on the seeds that were stored for 12 and 24 months. Species of the genus Acremonium were predominant on the longest stored seeds.

Table 2. Incidence of fungi associated with Sida hermaphrodita seeds.

\begin{tabular}{cccccc}
\hline \multirow{2}{*}{ Seed Lot } & \multicolumn{5}{c}{ Incidence (\%) of Fungi * } \\
\cline { 2 - 6 } & Aa & Fus & Pen & Cla & Acr \\
\hline 2 months of storage & $34.74^{\mathrm{a}}$ & $0.35^{\mathrm{b}}$ & 3.16 & $8.07^{\mathrm{a}}$ & $11.23^{\mathrm{b}}$ \\
12 months of storage & $45.09^{\mathrm{a}}$ & $0^{\mathrm{b}}$ & 4.21 & $0.53^{\mathrm{b}}$ & $6.14^{\mathrm{b}}$ \\
24 months of storage & $18.24^{\mathrm{b}}$ & $1.58^{\mathrm{a}}$ & 2.11 & $0^{\mathrm{b}}$ & $27.72^{\mathrm{a}}$ \\
\hline
\end{tabular}

a, $\mathrm{b}$ Means in the same column followed by the same letter do not differ significantly in Fisher's LSD test at $p<0.05$. * Aa-Alternaria alternata, Fus-Fusarium spp., Pen-Penicillium spp., Cla-Cladosporium spp., AcrAcremonium spp.

\subsection{Molecular Identification of Alternaria alternata}

A comparative analysis of the sequences of nine A. alternata isolates confirmed their affiliation with this species. The BLASTn analysis revealed 100\% homology between most of the analyzed isolates and A. alternata isolates responsible for garlic diseases in China and Mexico. Alternaria alternata isolate W 26 had an identical sequence to the A. alternata isolate responsible for Panax notoginseng root rot in China. The sequence of A. alternata P 1 was identical to the causal agent of watermelon diseases in Bangladesh, and the sequence of $A$. alternata $\mathrm{P} 5$ was identical to the pathogen responsible for mulberry leaf spot disease in India. Only A. alternata P 2 showed 99\% homology with the isolate responsible for garlic disease in Mexico. The boundaries between Alternaria species belonging to section Alternaria proposed by Woudenberg et al. (2015) were preserved in the analyzed isolates. Amplification products had the size of 580 nucleotides for ITS-I-5.8SrDNA-ITS-II region, 600 nucleotides for the Alta1 gene, 600 nucleotides for the $g d p$ gene, and 590 nucleotides for the Alta1 gene. The presence of Alta1 gene markers was confirmed in A. alternata isolates P 2, P 5, P 8, S 22, P 25 and W 26, and their sequences corresponded to the sequences of A. alternata (MT140362, MN184998, MT074730). In all isolates, the partial sequences of $T E F 1 a$ and $g d b$ genes corresponded to the partial sequences of these genes in A. alternata (MF033834, KP057228, KP851967, MF033834, MN970210).

\subsection{Pathogenicity of A. alternata in the Detached Leaf Bioassay}

Five isolates (A. alternata W 26, P 25, S 22, P5 and P 2) were pathogenic in the detached leaf bioassay. Black spots with a diameter of $0.2-10 \mathrm{~mm}$ were observed on leaves 4 days after inoculation (Figure 3). These symptoms were identical to those observed on the leaves of Virginia fanpetals in early stages of infection in the plantation. Alternaria alternata W 26 was the most pathogenic isolate which caused black spots with a combined area of $101.8 \mathrm{~mm}^{2}$ on the inoculated leaves (Figure 4). The isolates that caused pathogenic symptoms on leaves were identified as A. alternata because the same pathogen was reisolated from infected tissues, thus fulfilling Koch's postulates. Detached leaves inoculated with A. alternata isolates W 27, P 8, P 1 and P 3 did not display symptoms of infection. 


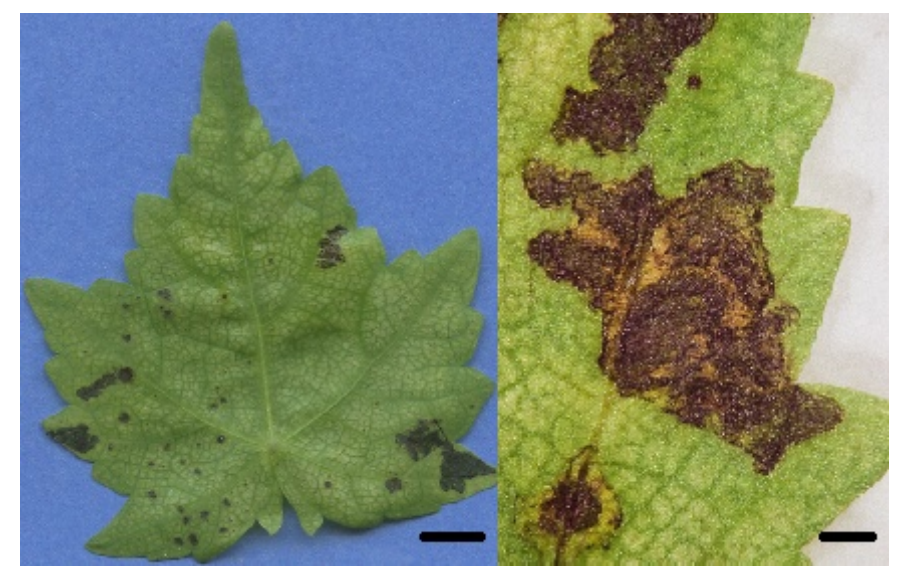

Figure 3. Necrotic changes on Virginia fanpetals leaves in Koch's test (right, scale bar $=2 \mathrm{~cm}$ ) viewed under a stereo microscope (right, scale bar $=2 \mathrm{~mm}$ ).

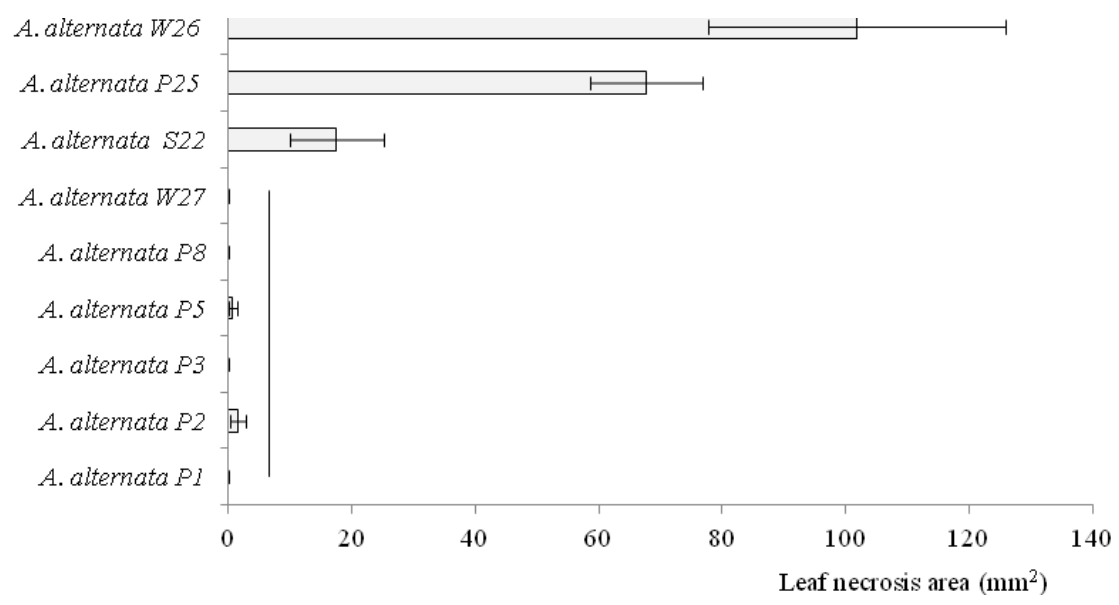

Figure 4. Pathogenicity of Alternaria alternata isolates in the detached leaf bioassay. Means followed by the same letter do not differ significantly in Fisher's LSD test at $p<0.05$.

\subsection{Seed Transmission Test}

A standard seed germination test demonstrated that only $50.5 \%$ of the seeds produced healthy seedlings; $44 \%$ of the seeds did not germinate or the emerged seedlings were small and deformed; and $5.5 \%$ of the seeds were infected (black or with black spots).

An evaluation of Virginia fanpetals seedlings grown in a greenhouse from seeds that were naturally colonized by A. alternata (based on the results of the seed germination test) revealed that the pathogen was transmitted from seeds to seedlings. The small $(3-5 \mathrm{~mm})$ and larger $(>5 \mathrm{~mm})$ black spots were observed on all leaves of 8-week-old seedlings. The mean incidence rate was estimated at $5.01 \%$ in all replications (Table 3, Figure S1). Severely infected leaves turned yellow, but stems were not infected. Additional seed inoculation with a suspension of A. alternata spores did not significantly contribute to disease symptoms. A morphological analysis of the pathogen isolated from necrotic leaf tissues confirmed that these changes were caused by A. alternata.

Additional seed inoculation with the virulent $A$. alternata isolate W 26 significantly inhibited germination (Table 3). The number of seedlings was $38.93 \%$ lower in pots with inoculated seeds than in pots where the planted seeds were non-inoculated by pathogen. The seedlings growing from inoculated seeds were also significantly shorter and had significantly fewer leaves. 
Table 3. The effect inoculation of seed on the growth of Sida hermaphrodita seedlings in a greenhouse.

\begin{tabular}{|c|c|c|c|c|c|c|}
\hline \multirow[b]{2}{*}{ Inoculation } & \multicolumn{5}{|c|}{ Morphology of Virginia Fanpetals Seeds } & \multirow{2}{*}{$\begin{array}{c}\text { Leaves } \\
\text { Infected by } \\
\text { A. alternata } \\
\text { (Mean Score) }\end{array}$} \\
\hline & $\begin{array}{c}\text { Seedling } \\
\text { Height }(\mathrm{cm})\end{array}$ & $\begin{array}{l}\text { Root Length } \\
\text { (cm) }\end{array}$ & No. of Leaves & $\begin{array}{c}\text { Seedling } \\
\text { Weight (g) }\end{array}$ & $\begin{array}{c}\text { Seed } \\
\text { Germination } \\
\text { Capacity }(\%)\end{array}$ & \\
\hline Control & $6.31^{\mathrm{a}}$ & 3.5 & $3.16^{\mathrm{a}}$ & 0.51 & $45.03^{a}$ & 5.01 \\
\hline A. alternaria & $5.07^{b}$ & 3.16 & $2.51^{b}$ & 0.62 & $27.5^{\mathrm{b}}$ & 5.33 \\
\hline
\end{tabular}

a,b Means in the column followed by the same letter do not differ significantly in Fisher's LSD test at $p<0.05$.

\subsection{Biological Control In Vitro and in Greenhouse}

In comparison with non-dressed control seeds, all A. pullulans isolates inhibited the growth of A. alternata on dressed seeds in vitro (Figure 5). Aureobasidium pullulans isolate Ap 3 was most effective in reducing the number of seeds infected with A. alternata. The presence of A. alternata colonies was observed on only $8.67 \%$ of the seeds dressed with a suspension of A. pullulans isolate Ap 3. In contrast, A. alternata colonized $30.68 \%$ of non-dressed control seeds. All antagonistic isolates limited disease symptoms in plants grown from non-inoculated seeds in the greenhouse (Figure 6). Aureobasidium pullulans isolate Ap 1 was most effective in reducing leaf area infected with $A$. alternata, by up to $43.72 \%$ in comparison with inoculated control seedlings. Additionally, in the greenhouse experiment, all isolates enhanced the germination capacity of inoculated seeds (Figure 7). In the greenhouse experiment, A. pullulans isolates Ap 1 and Ap 4 were particularly effective in minimizing the adverse effects of seed inoculation with $A$. alternata. The application of these isolates increased seed germination by around $60 \%$ relative to the inoculated control.

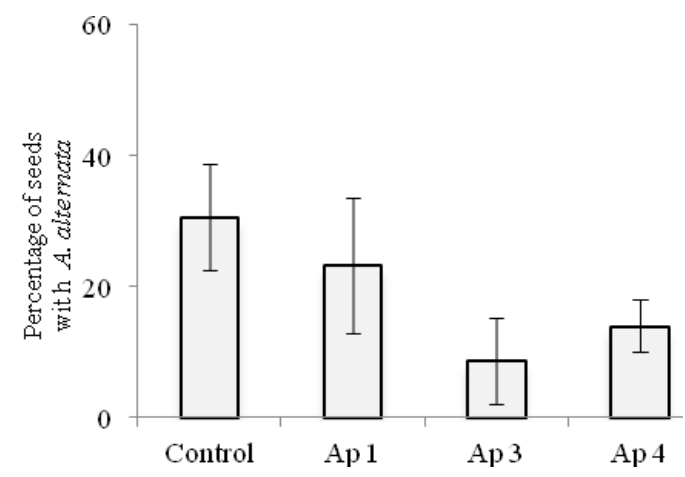

Figure 5. Percentage of Sida hermaphrodita seeds colonized by Alternaria alternata after treatment in vitro by Aureobasidium pullulans isolates Ap 1, Ap 3 and Ap 4.

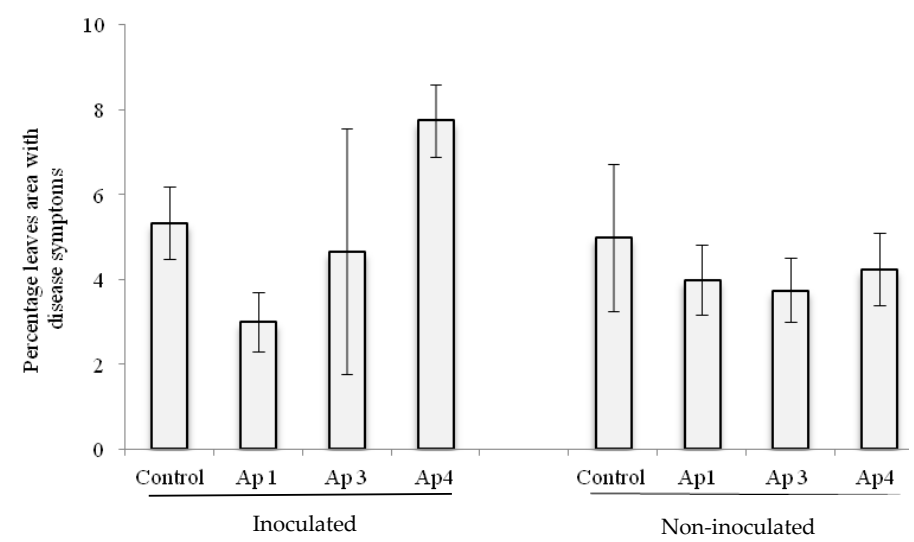

Figure 6. Effect dressing of seeds with Aureobasidium pullulans (Ap 1, Ap 3 and Ap 4) yeast suspensions on infection leaves Sida hermaphrodita by Alternaria alternata in greenhouse. 


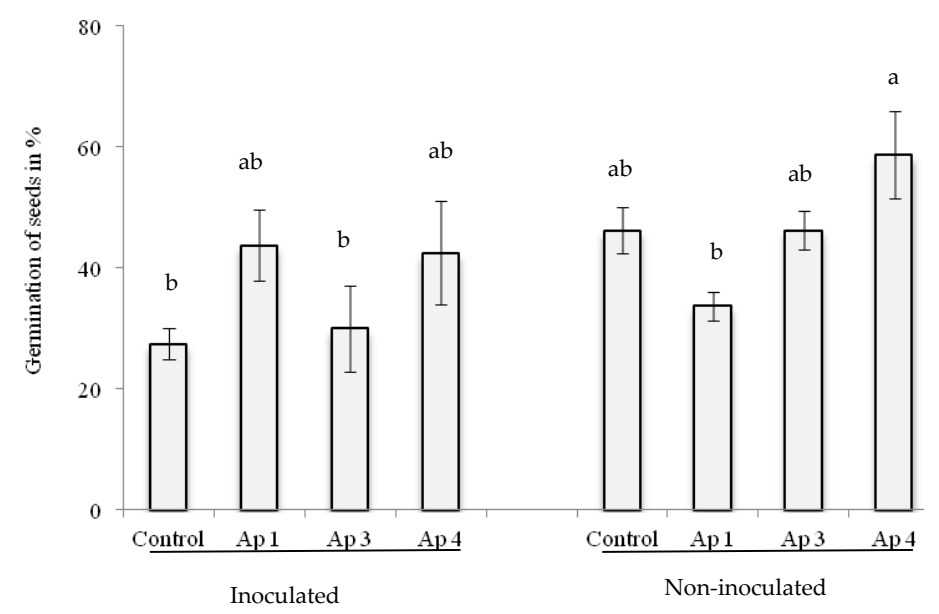

Figure 7. Effect dressing of seeds with Aureobasidium pullulans (Ap 1, Ap 3 and Ap 4) yeast suspensions on Sida hermaphrodita seeds germination in greenhouse. Means followed by the same letter do not differ significantly in Fisher's LSD test at $p<0.05$.

\section{Discussion}

Low field emergence, seedling loss in the first year of cultivation caused by various physiological factors, including dormancy, and phytopathological factors such as colonization by pathogenic fungi and the presence of pathogenic inocula in soil that cause root rot before and after seedling emergence pose significant problems in the cultivation of Virginia fanpetals [4]. Reliable evaluations of seed health are crucial in the production of seeds and seedlings. Such tests also prevent the spread of A. alternata to other regions, which is a very important consideration in view of the pathogen's allergenic and toxic properties [17,27].

Only $50.5 \%$ of the analyzed Virginia fanpetals seeds germinated, which implies that the tested material did not meet the standards of the International Seed Testing Association (ISTA) [39]. Only $45.03 \%$ of the seeds that were planted in greenhouse pots produced seedlings. Similar results were reported by Grzesik et al. [44] and Seletnik et al. [45] who determined the germination rate of Virginia fanpetals seeds at $30-50 \%$. Seed dormancy manifested by reduced seed germination capacity poses a problem in the sexual reproduction of Virginia fanpetals. Members of the family Malvaceae are characterized by physical seed dormancy due to the presence of water-impermeable palisade cells in the seed coat which are impregnated with hydrophobic substances such as suberin, cutin and lignin [46]. The seed embryo is fully developed and non-dormant. The seed coat becomes permeable when the palisade layer is opened or damaged. In nature, the seed coat may be damaged by microorganisms, changes in temperature, freezing, thawing, fire or enzymes in the gastrointestinal tract of animals [47]. For commercial purposes, seeds can be scarified mechanically, chemically or thermally. Seed dormancy in crop plants poses numerous difficulties in the production process, including problems with evaluating the quality of seed material. Special treatments may be required to break dormancy, which increases cultivation costs.

The role of pathogens in inhibiting seed germination and the growth and development of Virginia fanpetals seedlings has not been researched extensively to date. The majority of phytopathological analyses were conducted on S. sclerotiorum, the causal agent of white mold which poses the most serious threat to commercial plantations of Virginia fanpetals in Poland $[9,11,12]$. Filaments and sclerotia of S. sclerotiorum were previously identified in soybeans and beans [48]. In a study by de Carvalho et al. [49], S. sclerotiorum was also transmitted from infected soybean seeds to seedlings.

The harmful effects of Alternaria spp. on Virginia fanpetals have not been identified to date. The majority of species of the genus Alternaria are saprotrophs which colonize dead plant tissue in soil [30]. Several species are the pathogens which damage cereal crops, oil plants, vegetables (cauliflower, broccoli, carrots, potatoes), fruit (tomatoes, citrus 
fruit, apples) and ornamental plants. Alternaria spp. fungi are generally referred to as post-harvest pathogens which cause seedling root rot in major crop plants [50].

There are no published studies on the colonization of Virginia fanpetals seeds by A. alternata. However, previous research has demonstrated that this fungal pathogen can colonize the seeds of other plant species of the family Malvaceae. According to Rodríguez and Garcia [51], the growth of Sida rhombifolia (arrowleaf sida) seedlings was significantly compromised by pests and pathogens, including A. alternata, which damaged $40 \%$ of the planted seeds. Fungal pathogens of the genus Alternaria were also identified in the seeds of okra, an edible plant of the family Malvaceae which is widely grown in India [52,53].

Phytopathological problems can be partially solved by seed dressing. According to Borkowska [46], in successive years of the experiment, seed dressing contributed to a significant increase in stem dry weight (approx. $2 \mathrm{t}$ ) and energy (approx. $40 \mathrm{GJ}$ ) per ha of crops in comparison with the control treatment comprising non-dressed seeds [54]. Virginia fanpetals seeds treated with fungicide were characterized by higher germination capacity in laboratory and greenhouse experiments, whereas the tebuconazole fungicide delivered a strongly phytotoxic effect and inhibited seed germination [12]. Little is known about seed dressing in Virginia fanpetals, and further research is needed.

This pioneering study demonstrated that $A$. alternata fungi can be transmitted from seeds to seedlings. Black spots and yellowing leaves were observed in the infected seedlings. In this experiment, Virginia fanpetals plants grown in a plantation displayed symptoms of disease that are typically observed in the family Malvaceae. According to Kumar [55], A. alternata colonizes okra fruit and causes post-harvest diseases. The symptoms of infection described by Dadabhau [21] on the leaves of okra plants grown in India are similar to the pathological changes noted in this study. Identical symptoms (dark brown spots with a chlorotic halo) caused by A. alternata were reported in annual Hibiscus syriacus plants of the family Malvaceae in 2019 in northern Italy [20].

The dressing of seeds with A. pullulans Ap 4 yeast suspensions had contributed to a significant increase in seed germination capacity which reached $58.75 \%$ in comparison with $27.50 \%$ in the inoculation control treatment. This is a highly interesting result from the practical point of view. Seed dormancy manifested by reduced seed germination capacity poses a problem in the sexual reproduction of Virginia fanpetals. Members of the family Malvaceae are characterized by physical seed dormancy due to the presence of waterimpermeable palisade cells in the seed coat which are impregnated with hydrophobic substances such as suberin, cutin and lignin [46]. The seed embryo is fully developed and non-dormant. The seed coat becomes permeable when the palisade layer is opened or damaged. In nature, the seed coat may be damaged by microorganisms, changes in temperature, freezing, thawing, fire or enzymes in the gastrointestinal tract of animals [39]. For commercial purposes, seeds can be scarified mechanically, chemically or thermally. Seed dormancy in crop plants poses numerous difficulties in the production process, including problems with evaluating the quality of seed material. Special treatments may be required to break dormancy, which increases cultivation costs. Seed dressing with selected yeast isolates can improve seedling health and increase the germination capacity of Virginia fanpetals seeds which are often damaged by microorganisms under field conditions [15].

The search for effective biocontrol methods in the production of $S$. hermaphrodita is a timely problem in the context of the European Green Deal strategy promoting reduced pesticide use in agriculture [13]. The importance of biological protection methods was evidenced by this pioneering study which demonstrated that $A$. alternata fungi can be transmitted from seeds to seedlings and pose a problem for plants in later stages of development.

\section{Conclusions}

Alternaria alternata can strongly infect leaves and seed capsules in S. hermaphrodita. This pathogen can also be transmitted from seeds to plants. Aureobasidium pullulans can inhibit the progression of $A$. alternata infections in S. hermaphrodita and minimize the 
negative effects of $A$. alternata on seed germination. The results of in vitro and greenhouse experiments are promising, and they merit further research under field conditions to reduce pesticide use in agriculture.

Supplementary Materials: The following are available online at https:/ / www.mdpi.com/article/10 .3390 /agriculture11121264/s1, Figure S1: The small (3-5 mm) and larger ( $>5 \mathrm{~mm}$ ) black spots were observed on all leaves of 8-week-old seedlings.

Author Contributions: Conceptualization, U.W.; methodology, U.W., E.K. and W.P.; software, U.W.; validation, U.W.; formal analysis, U.W.; investigation, U.W., E.K. and W.P.; data curation, U.W., E.K. and W.P.; writing-original draft preparation, U.W.; writing-review and editing, U.W. and E.K.; supervision, U.W.; project administration, U.W.; funding acquisition, U.W. All authors have read and agreed to the published version of the manuscript.

Funding: This research was funded by Minister of Science and Higher Education in the range of the program entitled "Regional Initiative of Excellence" for the years 2019-2022, Project No. 010/RID/2018/19.

Institutional Review Board Statement: Not applicable.

Informed Consent Statement: Not applicable.

Data Availability Statement: Data supporting reported results can be found in University of Warmia and Mazury in Olsztyn, Department of Entomology, Phytopathology and Molecular Diagnostic, Prawocheńskiego 17, 10-721 Olsztyn.

Acknowledgments: Project financially supported by the Minister of Education and Science under the program entitled "Regional Initiative of Excellence" for the years 2019-2022, Project No. 010/RID/2018/19, amount of funding 12.000.000 PLN.

Conflicts of Interest: The authors declare no conflict of interest.

\section{References}

1. Spooner, D.M.; Cusick, A.W.; Hall, G.F.; Baskin, J.M. Observations on the distribution and ecology of Sida hermaphrodita (L.) Rusby (Malvaceae). Sida Contrib. Bot. 1985, 11, 215-225.

2. Stolarski, M.J. Industrial and bioenergy crops for bioeconomy development. Agriculture 2021, 11, 852. [CrossRef]

3. Borkowska, H.; Molas, R.; Kupczyk, A. Virginia fanpetals (Sida hermaphrodita Rusby) cultivated on light soil; height of yield and biomass productivity. Pol. J. Environ. Stud. 2009, 18, 563-568.

4. Borkowska, H.; Molas, R. Two extremely different crops, Salix and Sida, as sources of renewable bioenergy. Biomass Bioenergy 2012, 36, 234-240. [CrossRef]

5. Kocoń, A.; Jurga, B. The evaluation of growth and phytoextraction potential of Miscanthus $\times$ giganteus and Sida hermaphrodita on soil contaminated simultaneously with Cd, Cu, Ni, Pb, and Zn. Environ. Sci. Pollut. Res. 2017, 24, 4990-5000. [CrossRef]

6. Ignatowicz, K. The assessment usability of Virgina mallow Sida hermaphrodita for phytoremediation of soil contaminated with pesticides. Ecol. Eng. 2015, 45, 89-92. [CrossRef]

7. Lewtak, K.; Fiołka, M.J.; Czaplewska, P.; Macur, K.; Kaczyński, Z.; Buchwald, T.; Szczuka, E.; Rzymowska, J. Sida hermaphrodita seeds as the source of anti-Candida albicans activity. Sci. Rep. 2019, 9, 12233. [CrossRef]

8. Mangwende, E.; Kritzinger, Q.; Truter, M.; Aveling, T.A.S. Alternaria alternata: A new seed-transmitted disease of coriander in South Africa. Eur. J. Plant. Pathol. 2018, 152, 409-416. [CrossRef]

9. Łacicowa, B.; Kiecana, I. White mold-A dangerous disease affecting Sida hermaphrodita (L.) Rusby. Ochrona Roślin. 1991, 10, 16-17. (In Polish)

10. Kalembasa, D.; Jaremko, D.; Bik, B.; Karczmarek, J.; Jędryczka, M. Effect of infection of Virginia mallow shoots by fungus Sclerotinia sclerotiorum on the contents and distribution of aluminium, manganese and iron. Acta Sci. Pol. Agric. 2016, $15,39-47$.

11. Remlein-Starosta, D.; Nijak, K. Virginia mallow-First results on investigation on possibilities of pest and diseases control. Prog. Plant Prot. 2007, 47, 358-362. (In Polish)

12. Remlein-Starosta, D. Epidemic incidence of Sclerotinia rot on Virginia mallow. Prog. Plant Prot. 2009, 49, 705-709. (In Polish)

13. European Green Deal. Available online: https://ec.europa.eu $\backslash \mathrm{T} 1 \backslash$ guilsinglrighteu-action $\backslash \mathrm{T} 1 \backslash$ guilsinglrighteuropean-greendeal_pl (accessed on 18 October 2021).

14. Kandula, J.; Kaur, H.; Alizadeh, H.; Hampton, J.G. Disease Control and Plant Growth Promotion of Miscanthus $\times$ giganteus with Trichoderma Bio-Inoculants. In Track 2-2-1: Plant Diseases, Insect Pests and Weed Management, International Grassland Congress; Available online: https:/ / uknowledge.uky.edu (accessed on 18 October 2021).

15. Remlein-Starosta, D.; Krzymińska, J.; Kowalska, J.; Bocianowski, J. Evaluation of yeast-like fungi to protect Virginia mallow (Sida hermaphrodita) against Sclerotinia sclerotiorum. Can. J. Plant Sci. 2016, 96, 243-251. [CrossRef] 
16. Huang, H.; Tian, C.; Huang, Y.; Huang, H. Biological control of poplar anthracnose caused by Colletotrichum gloeosporioides (Penz.) Penz. \& Sacc. Egypt J. Biol. Pest Control 2020, 30, 104. [CrossRef]

17. Meena, M.; Gupta, S.K.; Swapnil, P.; Zehra, A.; Dubey, M.K.; Upadhyay, R.S. Alternaria toxins: Potential virulence factors and genes related to pathogenesis. Front. Microbiol. 2017, 8, 1451. [CrossRef]

18. Lanzuise, S.; Cozzolino, A.; Gualtieri, L.; Parrella, G.; Ruocco, M. First report of brown leaf spot caused by Alternaria alternata on cast iron plant (Aspidistra elatior) in Italy. J. Plant Pathol. 2018, 100, 117. [CrossRef]

19. Alam, M.W.; Rehman, A.; Malik, A.U.; Aslam, S.; Sarwar, M.; Ali, S.; Khan, M.A.; Hameed, A.; Sarfraz, S. First report of Alternaria alternata causing postharvest fruit rot of peach in Pakistan. J. Plant Pathol. 2018, 101, 209. [CrossRef]

20. Garibaldi, A.; Tabone, G.; Matić, S.; Luongo, I.; Gullino, M.L. First report of Alternaria alternata causing leaf spots on Hibiscus syriacus in Italy. J. Plant Pathol. 2020, 102, 953. [CrossRef]

21. Dadabhau, P.A. Investigation on Leaf Spot (Alternaria alternata (Fr.) Keissler.) Disease of Okra (Abelmoschus esculentus L.) under South Gujarat Conditions. Master's Thesis, N.M. College of Agriculture Gujarat Agricultural University, Navsari, India, 2009; p. 155.

22. Bassimba, D.D.M.; Mira, J.L.; Vicent, A. Inoculum sources, infection periods, and effects of environmental factors on Alternaria brown spot of mandarin in Mediterranean climate conditions. Plant Dis. 2014, 98, 409-417. [CrossRef]

23. Vu, A.L.; Dee, M.M.; Russell, T.; Zale, J.; Gwinn, K.D.; Ownley, B.H. First report of leaf spot caused by Alternaria alternata on Switchgrass in Tennessee. Plant Dis. 2012, 96, 763. [CrossRef] [PubMed]

24. Pusz, W.; Urbaniak, J. Foliar diseases of willows (Salix spp.) in selected locations of the Karkonosze Mts. (the Giant Mts). Eur. J. Plant Pathol. 2017, 148, 45-51. [CrossRef]

25. Szpunar-Krok, E.; Stompor-Chrzan, E.; Grochowska, S.; Bobrecka-Jamro, D. Evaluation of the health of energetic crops in Podkarpacie region. Prog. Plant Protec. 2017, 3, 196-200. [CrossRef]

26. Salo, P.M.; Arbes, S.J.; Sever, M.; Jaramillo, R.; Cohn, R.D.; London, S.J.; Zeldin, D.C. Exposure to Alternaria alternata in US homes is associated with asthma symptoms. J. Allergy Clin. Immunol. 2006, 118, 892-898. [CrossRef] [PubMed]

27. Gabriel, M.F.; Postigo, I.; Tomaz, C.T.; Martínez, J. Alternaria alternata allergens: Markers of exposure, phylogeny and risk of fungi-induced respiratory allergy. Environ. Int. 2016, 89-90, 71-80. [CrossRef] [PubMed]

28. EFSA Panel on Contaminants in the Food Chain (CONTAM). Scientific opinion on the risks for animal and public health related to the presence of Alternaria toxins in feed and food. EFSA J. 2011, 9, 2407. [CrossRef]

29. Ellis, M.B. Demataceous Hyphomycetes; The Eastern Press: London, UK, 1971; p. 608.

30. Woudenberg, J.H.C.; Groenewald, J.Z.; Binder, M.; Crous, P.W. Alternaria redefined. Stud. Mycol. 2013, 75, 171-212. [CrossRef]

31. Woudenberg, J.H.C.; Seidl, M.F.; Groenewald, J.Z.; de Vries, M.; Stielow, J.B.; Thomma, B.P.H.J.; Crous, P.W. Alternaria section Alternaria: Species, formae speciales or pathotypes? Stud Mycol. 2015, 82, 1-21. [CrossRef]

32. White, T.J.; Bruns, T.; Lee, S.; Taylor, J. PCR Protocols: A Guide to Methods and Applications, Amplification and Direct Sequencing of Fungal Ribosomal RNA Genes for Phylogenetics; Innis, M.A., Gelfand, D.H., Sninsky, J.J., White, T.J., Eds.; Academic Press, Inc.: New York, NY, USA, 1990; pp. 315-322.

33. Duba, A.; Goriewa, K.; Wachowska, U.; Wiwart, M. Alternaria alternata (Fr.) Keissl with mutation G143A in the Cyt $b$ gene is the source of a difficult-to-control allergen. Environ. Sci. Pollut. Res. Int. 2018, 25, 469-478. [CrossRef] [PubMed]

34. Ramires, F.A.; Masiello, M.; Somma, S.; Villani, A.; Susca, A.; Logrieco, A.F.; Luz, C.; Meca, G.; Moretti, A. Phylogeny and mycotoxin characterization of Alternaria species isolated from wheat grown in Tuscany, Italy. Toxins 2018, 10, 472. [CrossRef]

35. PAS. Available online: www.ibb.waw.pl (accessed on 12 October 2020).

36. Genomed. Available online: http://www.genomed.pl (accessed on 2 February 2020).

37. BLAST. Available online: https://blast.ncbi.nlm.nih.gov / Blast.cgi (accessed on 10 January 2021).

38. Kgatle, M.G.; Truter, M.; Ramusi, T.M.; Flett, B.; Aveling, T.A.S. Alternaria alternata, the causal agent of leaf blight of sunflower in South Africa. Eur. J. Plant. Pathol. 2018, 151, 677-688. [CrossRef]

39. ISTA (International Seed Testing Association). International Rules for Seed Testing. Proceedings of the International Seed Testing Association. Available online: https://www.seedtest.org/en/international-rules-for-seed-testing-_content---1--1083. html (accessed on 10 January 2021).

40. Rasband, W.S. ImageJ; U.S. National Institute of Health: Bethesda, MD, USA, 2016. Available online: http:/ /imagej.nih.gov/ij/ (accessed on 10 October 2020).

41. Eppo, C. European and Mediterranean Plant Protection Organization Guideline for the Efficacy Evaluation of Fungicides. Foliar Dis. Cereals 1998, 28, 279-290.

42. Wachowska, U.; Irzykowski, W.; Jędryczka, M. Agrochemicals: Effect on genetic resistance in yeasts colonizing winter wheat kernels. Ecotoxicol. Environ. Saf. 2018, 162, 77-84. [CrossRef]

43. Hoagland, D.R.; Arnon, D.I. The Water-Culture Method for Growing Plants without Soil; University of California, College of Agriculture, Agricultural Experiment Station: Upper Darby, PA, USA, 1950; p. 347.

44. StatSoft Inc. STATISTICA (Data Analysis Software System); Version 12; StatSoft Inc.: Palo Alto, CA, USA; Available online: Www.statsoft.com (accessed on 20 September 2021).

45. Grzesik, M.; Janas, R.; Romanowska-Duda, Z. Stimulation of growth and metabolic processes in Virginia mallow (Sida hermaphrodita L. Rusby) by seed hydroconditioning. Probl. Inżynierii Rol. 2011, 4, 81-89. 
46. Saletnik, B.; Bajcar, M.; Zakuła, G.; Saletnik, A.; Tarapatskyy, M.; Puchalski, C. Biochar as a stimulator for germination capacity in seeds of Virginia mallow (Sida hermaphrodita (L.) Rusby). Appl. Sci. 2019, 9, 3213. [CrossRef]

47. Baskin, J.M.; Baskin, C.C. A classification system for seed dormancy. Seed Sci. Res. 2004, 14, 1-16. [CrossRef]

48. Argel, P.J.; Paton, C.J. Tropical and Subtropical Species. In Forage Seed Production, Overcoming Legume Hardseedeness; Loch, D.S., Ferguson, J.E., Eds.; CAB International: Wallingford, UK, 1999; Volume 2, pp. 247-259.

49. Dos Santos, R.R.; de Morais, T.P.; Juliatti, F.C. Detection of Sclerotinia sclerotiorum on soybean and common bean seeds by modified Neon-s test. Biosci. J. Uberlândia 2018, 34, 67-74. [CrossRef]

50. De Carvalho, C.; Forti, V.A.; Bonfim, M.F.; Moraes, M.H.D.; Menten, J.O.M. Transmission of Sclerotinia sclerotiorum from soybean seed to seedlings. Rev. Agric. 2016, 91, 67-80. [CrossRef]

51. Thomma, B.P. Alternaria spp.: From general saprophyte to specific parasite. Mol. Plant Pathol. 2003, 4, 225-236. [CrossRef]

52. Rodríguez, C.; Garcia, M.A. Seed-bank dynamics of the tropical weed Sida rhombifolia (Malvaceae): Incidence of seedling emergence, predators and pathogens. Seed Sci. Res. 2009, 19, 241-248. [CrossRef]

53. Agrawal, S. Seed-Borne and Post-Harvest Diseases of Okra [Ablemoschus esculentus L. (Monech)]. Ph.D. Thesis, University of Rajasthan, Jaipur, India, 2000; p. 121.

54. Begum, M.; Lokesh, S.; Ravishankar, R.V.; Shailaja, M.D.; Kumar, T.V.; Shetty, H.S. Evaluation of certain storage conditions for okra (Abelmoschus esculentus (L.) Moench) seeds against potential fungal pathogens. Int. J. Agric. Biol. 2005, 7, 550-554.

55. Borkowska, H. Seed germination and field emergence ability of Virginia mallow depending on applied seed treatment. Fragm. Agron. 2006, 3, 269-276. 